\title{
Revisiting Share Market Efficiency: Evidence from the New Zealand Australia, US and Japan Stock Indices
}

\author{
${ }^{1}$ Christopher Gan, ${ }^{2}$ Minsoo Lee, ${ }^{3} \mathrm{Au}$ Yong Hue Hwa and ${ }^{4}$ Jun Zhang \\ ${ }^{1}$ Commerce Division, PO Box 84, Lincoln University, Canterbury, New Zealand \\ ${ }^{2}$ Economics Department, American University Sharjah, Sharjah, United Arab Emirates \\ ${ }^{3}$ Department of Accounting and Finance, Faculty of Business and Economics \\ Monash University, VIC3800 Australia \\ ${ }^{4}$ Commerce Division, P.O. Box 84, Lincoln University, Canterbury, New Zealand
}

\begin{abstract}
This study aims to re-examine the market efficiencies in New Zealand Stock Exchange (NZSE) and Australia Stock Exchange (ASX) stock indices to investigate whether Groenewold' $\mathrm{s}^{[1]}$ findings still hold in the period after the financial liberalization (January 1990-January 2003). In addition, the study also examines whether the larger US NYSE and Japanese NIKKEI stock indices have any influence on the NZSE and ASX indices. Similar to Groenewold's findings, we find evidence of weak form efficiency for NZSE and ASX stock indices using the Augmented-Dickey Fuller and Philip-Perron unit root tests. In contrast to Groenewold's findings, the Engle-Granger cointegration test results suggest that the NZSE stock index is cointegrated with and granger caused by the ASX index, both violating the semi-strong form market efficiency of NZSE. Although the NZSE is a small stock market, its stock index is relatively independent with respect to the NYSE and NIKKEI stock indices.
\end{abstract}

Key words: Share Returns, Macroeconomic Variables, Cointegration, Granger-causality

\section{INTRODUCTION}

Market efficiency has traditionally been associated with the absence of predictability of returns because if the returns are predictable, profit-maximizing investors will exploit the profit opportunities until the predictability disappears ${ }^{[1]}$. To date, there exists a large body of empirical literature testing the efficient market theory in the equity market around the world. Most of these studies employ the event study's methodology, where market response in relation to a particular company announcement is analyzed. Other studies, for example Groenewold ${ }^{[1]}$, examine market efficiency by investigating the equity market as a whole.

Groenewold ${ }^{[1]}$ investigate the weak and semistrong form efficiency of Australia and New Zealand market during the period of 1975-1992. The weak form efficiency is tested by examining the predictability of the index based only on its own past values using unit root tests, while semi-strong efficiency examines predictability based on other publicly available information using cointegration and granger causality tests. The share price index for the other country is regarded as 'other publicly available information' in his study. The author found the existence of both the weak form efficiency and semi-strong form market efficiency. However, there was an evidence of Grangercausality in both directions using daily data is employed.

In this study, we follow the approach of Groenewold $^{[1]}$ in testing the market efficiency of the New Zealand Stock Exchange (NZSE) stock index and its major trading partner, the Australian Stock Exchange (ASX) stock index during the period of January 1990 to January 2003. Our investigation updates Groenewold ${ }^{[1]}$ study and facilitates comparison of equity market efficiency over time. Prior to financial liberalization in the 1980s for both New Zealand and Australia, there were significant barriers to international capital flows and trade. In recent years, the significant improvements in telecommunications and computer technology have made the international flow of information cheaper and more reliable ${ }^{[3]}$ which possibly improve market information efficiency.

However, the significant increase in international capital flow and cross-listing of companies also made international stock markets more integrated, where lead-lag relationships can often be identified between markets. The existence of stock market return predictability is a violation of the efficient market hypothesis. Whether the New Zealand Stock Exchange Index and Australia Stock Exchange Index are still efficient during our sample period of the postliberalization is an interesting empirical issue.

In addition, we also extend Groenewold ${ }^{[1]}$ study by investigating the efficiency of Japan Nikkei and US New York Stock Exchange (NYSE) stock indices. In particular, we are interested in testing the efficiency of New Zealand Stock Exchange Index by employing the Japan Nikkei Index, US New York Stock Exchange Index as 'other publicly available information' individually and as a group.

Previous studies that investigate whether the equity markets are driven by the stock markets of US and Japan typically focus on the stock markets of developing Asian countries ${ }^{[4]}$ and Australia ${ }^{[5]}$. Thus, this study will also contribute to the literature in testing the efficiency of New Zealand stock exchange index, taking into account information from the US and Japanese stock indices. In previous literature, US stock index is often identified as the most influential in the Asia-Pacific region while mixed results are often found in the Japanese stock index. 
The unique institutional characteristics of New Zealand Stock Exchange provide an interesting setting for such investigation. Although the New Zealand equity market is small and comparatively illiquid, it is one of the least regulated stock markets in the world relative to other Asian stock markets, where a high degree of government intervention exists ${ }^{[6]}$. Our investigation will help answer the following two questions: is there market efficiency in a small and comparatively liquid equity market? Does the movement of a small equity market depend on other larger equity markets such as the US and Japan, an indication of market inefficiency?

Findings of market inefficiency would suggest that there are opportunities for investors to obtain abnormal returns in a particular equity market by observing pastor publicly available information. When policy makers find that the movement of a particular stock index is dependent on the other country's stock index they need to be aware of information affecting the other country as it would affect the home equity market as well.

Our results show an evidence of weak form efficiency for NZSE and ASX indices using the Augmented-Dickey Fuller and Philip-Perron unit root tests ${ }^{[7]}$. In contrast to Groenewold ${ }^{[1]}$, the Engle-Granger cointegration test result indicated the NZSE stock index is cointegrated with and Granger-caused by the Australian Stock index, both violating the semi-strong form market efficiency. Although the NZSE is a small stock market, the stock index is relatively independent with respect to the NYSE and NIKKEI stock indices; it is neither Granger-caused by nor cointegrated with both the US and Japan.

Background: The New Zealand Stock Exchange (NZSE) is one of the least regulated stock markets in the world. Since the deregulation of the financial markets in 1984, the NZSE has developed a selfregulatory model with minimal government intervention. Compared to most other countries, New Zealand does not impose any statutory control on the Stock Exchange's listing rules. Insider trading in the NZSE is considered a civil offense compared to criminal offense in the US and Japan ${ }^{[8]}$.

Before May 2003, the NZSE publishes five stock indexes namely, the NZSE10, NZSE30, NZSE40, NZSESC and NZSEALL. The NZSE40 is the main public market index used and covered the top 40 largest and most frequently traded stocks listed on the NZSE. On the other hand the NZSESC is made up of all small companies that are not included in the NZSE40 index. This study uses the NZSE40 together with the NZSEALL as a proxy for the movement of the New Zealand stock market. Before 1992 Barclay's Index was the major NZSE market index until it was replaced by the NZSE40 in 1991. Barclay's Index comprises the top 40 stocks ranked by their market capitalization ${ }^{[9]}$. Thus, the Barclay's Index will be used as the proxy for NZSE stock index before 1992 in this study. From June 3, 2003 the NZSE changed to the NZX and the NZSE50 replaced the NZSE40 as the officially published New Zealand Stock Index. This change will not affect our findings.

As of 30 April 2003, there is a total of 196 companies listed on the NZSE market and 213 securities quoted. These securities have a total market capitalization of NZ\$42. 3 billion. In the four months ended 30 April 2003, a total of 2,494 million shares, with a value of $\$ 6,131$ million, was traded on the NZSE market. In comparison, in the four months ended 30 April 2002, the NZSE processed trade totalling 2,862 million shares with a value of $\$ 5,961$ million. Compared to the Australian Stock Exchange (ASX), as of 3 May 2003, there were a total of 1,425 companies listed with a market capitalization of AU\$ 676.822 billion. The average share price traded was AU\$2. 98. In May2, 2002 there were a total of 1,423 companies with a market capitalization of AU\$733. 8 billion. The average share price traded was AU\$ 3.45. (www.nzx.com, www.asx.com.au)

It is generally believed that the New Zealand stock market exhibited a semi-strong form or at least a weak form of efficiency. These issues were addressed by some researchers such as Groenewold ${ }^{[1]}$ who applied cointegration and Granger-causality tests to examine the Australian and New Zealand stock market efficiency.

According to Groenewold ${ }^{[1]}$, the weak form of market efficiency can be examined by the unit root tests of the Stock index. If the stock index just follows a random walk then the market under study can be regarded as in weak form efficiency because past stock indexes cannot be used to predict the current stock index.

Groenewold $^{[1]}$ used cointegration test to test the semi-strong form of market efficiency within New Zealand and Australian Stock Exchanges. The author found that both markets followed a semi-strong efficiency. Using the Granger-causality test the author also indicated that past returns help to explain the return to each other, although the explanatory power is quite small. Groenewold ${ }^{[1]}$ indicated that whether using New Zealand or Australian stock indexes as the dependent variable Engle-Granger's cointegration test results showed that there is no cointegration relationship between these two stock markets using daily frequency of data.

Cheung and $\mathrm{Ng}^{[10]}$, employed the Johnson's cointegration technique with quarterly data from Canada, Germany, Italy, Japan and US, conclude that there are long term comovements between the national stock index and some specific variables, such as real oil price, real consumption, real money supply and real GNP output in those five countries. Furthermore, the authors found that the real returns on stock indexes are, generally, related to deviations from empirical long-term relationships and to changes in macroeconomic variables.

\section{Data and Methodology}

Data: This study employs stock index data from four developed stock exchange indices, namely the New Zealand Stock Exchange stock index (NZSEALL) (Before 1992 Barclay's Index was the major NZSE market index until it is replaced in 1991 with the NZSE40. Thus, the Barclay's Index will be used as the proxy for NZSE stock index before 1992 in this study), Australia Stock Exchange stock index (ASX), Japan Stock Exchange stock index (Nikkei 225) and the US Stock Exchange stock index (NYSE). The time series of daily, weekly and monthly closing stock market indexes extracted from DataStream. The time span for the market efficiency test is from January 1990 to January 2003. The stock indexes employed in the various tests are expressed in terms of the natural logarithm. The summary statistics of daily, weekly and monthly stock price changes (returns) are reported in Table 1. 
Table 1: Summary Statistics on the Stock Return Series

\begin{tabular}{|c|c|c|c|c|}
\hline \multirow{2}{*}{$\begin{array}{l}\text { Stock Return } \\
\text { Daily }\end{array}$} & NZSE & ASX & NIKKEI & NYSE \\
\hline & & & & \\
\hline Mean $(* 10000)$ & 0.051 & 0.825 & -1.96 & 1.09 \\
\hline Max & 0.0399 & 0.0249 & 0.0540 & 0.0225 \\
\hline Min & -0.056 & -0.0304 & -0.0314 & -0.0295 \\
\hline Std. Dev. & 0.0041 & 0.0036 & 0.0065 & 0.0039 \\
\hline Skewness & -0.6447 & -0.4320 & 0.2636 & -0.2393 \\
\hline Kurtosis & 18.4943 & 7.7023 & 6.4758 & 7.5710 \\
\hline \multicolumn{2}{|c|}{ Sample Size 3412.00} & 2785.00 & $3414.00 \quad 3$ & 3414.00 \\
\hline \multicolumn{5}{|c|}{ Weekly } \\
\hline Mean $(* 10000)$ & 0.454 & 3.43 & -9.82 & 5.36 \\
\hline Max & 0.0422 & 0.0275 & 0.0527 & 0.0407 \\
\hline Min & -0.0398 & -0.0396 & -0.0473 & -0.0536 \\
\hline Std. Dev. & 0.0097 & 0.0079 & 0.0136 & 0.0093 \\
\hline Skewness & 0.0635 & -0.2210 & 0.0014 & -0.5019 \\
\hline Kurtosis & 4.8612 & 3.8298 & 4.1566 & 6.4941 \\
\hline Sample Size 6 & 681.00 & 682.00 & 682.00 & 682.00 \\
\hline \multicolumn{5}{|l|}{ Monthly } \\
\hline Mean $(* 10000)$ & 3.35 & 16.20 & -40.20 & 26.31 \\
\hline Max & 0.0555 & 0.0381 & 0.0840 & 0.0698 \\
\hline Min & -0.0650 & -0.0537 & -0.0929 & -0.0941 \\
\hline Std. Dev. & 0.0210 & 0.0167 & 0.0279 & 0.0197 \\
\hline Skewness & -0.1739 & -0.2161 & 0.1127 & -1.0503 \\
\hline Kurtosis & 3.1122 & 2.9211 & 3.7632 & 8.5306 \\
\hline Sample Size & 156.00 & 156.00 & 156.00 & 156.00 \\
\hline
\end{tabular}

Table 2: Pairwise Correlation of Daily, Weekly and Monthly Stock Returns

\begin{tabular}{lllll}
\hline Stock market & & Australia & Japan & US \\
\hline \multirow{2}{*}{ New Zealand } & Daily & 0.4889 & 0.2200 & 0.4000 \\
& Weekly & 0.3101 & 0.1713 & 0.3594 \\
& Monthly & 0.6548 & 0.2780 & 0.4008 \\
\hline Australia & Daily & & 0.3491 & 0.4918 \\
& Weekly & & 0.3154 & 0.5163 \\
& Monthly & 0.4243 & 0.5811 \\
\hline \multirow{2}{*}{ Japan } & Daily & & & 0.1393 \\
& Weekly & & & 0.2703 \\
& Monthly & & 0.3648 \\
\hline
\end{tabular}

Table 2 presents the pairwise correlation coefficients of the daily, weekly and monthly stock prices among these four countries. In the daily stock price series, the New Zealand stock price seems to be more correlated with Australia and least related to Japan. In the weekly stock price series the New Zealand stock price is most related to the US but still least related to Japan, the pairwise correction of monthly stock price series is similar to the daily stock price series.

Effect of Time Zone Differences: A major confusion encountered in the analysis of the international comovement of stock indexes is the non-overlapping trading hours of the markets. Eun and Shim ${ }^{[11]}$ indicated that a common approach to overcome this problem is to carefully examine the structure of the time differences and then incorporate it into the interpretation of the empirical results. The four stock indexes under study can be categorized into two types: New Zealand Japan and Australia can be categorized into the Pacific Rim time zone. These three markets are approximately in the same time zone, which minimize the non-overlapping markets problem.
Table 3: Pacific Rim Countries and the US Time Zone Comparison

\begin{tabular}{lllll}
\hline Time/Date & $11 \mathrm{pm}$ & $1 \mathrm{pm}$ & $2 \mathrm{pm}$ & $4 \mathrm{pm}$ \\
& $(2300 \mathrm{~h})$ & $(1300 \mathrm{~h})$ & $\begin{array}{l}(1400 \mathrm{~h}) \\
(1600 \mathrm{~h})\end{array}$ \\
& $29^{\text {th }}$ May, 03 & $30^{\text {th }}$ May 03 & $30^{\text {th }}$ May 03 & $30^{\text {th }} \quad$ May \\
03 & & & Sydney & Wellington \\
Cities & New York & Tokyo & Syd \\
\hline
\end{tabular}

Table 4: Opening and Closing Times of Four Stock Exchanges

\begin{tabular}{llll}
\hline Exchange markets: & $\begin{array}{l}\text { Opening } \\
\text { (Local) }\end{array}$ & $\begin{array}{l}\text { Closing } \\
\text { (Local) }\end{array}$ & $\begin{array}{l}\text { Closing } \\
\text { (Wellington time) }\end{array}$ \\
\hline New Zealand & $10.00 \mathrm{am}$ & $5.00 \mathrm{pm}$ & $5.00 \mathrm{pm}$ \\
Australia & $10.00 \mathrm{am}$ & $4.00 \mathrm{pm}$ & $6.00 \mathrm{pm}$ \\
Japan & $9.00 \mathrm{am}$ & $3.00 \mathrm{pm}$ & $6.00 \mathrm{pm}$ \\
US & $9.30 \mathrm{am}$ & $4.00 \mathrm{pm}$ & $11.00 \mathrm{pm} *$ \\
\hline
\end{tabular}

* These times are excluding the adjustment for daylight saving. It denotes the previous day in Wellington time.

However, the US stock market can be categorized into the second group, which is quite a different time zone from its Pacific Rim countries, which creates complications when evaluating the correlation problem between two markets. To illustrate, we will take NZSE as an example. Assuming it is now $4 \mathrm{pm}(1600 \mathrm{~h}), 30^{\text {th }}$ May 2003 in Wellington, then the time for the Pacific Rim countries in this research are shown in Table 3. The trading hours for these stock exchange markets are shown in Table 4.

From Table 4 the closing time for New Zealand Japan and Australia are approximately in the same time zone, only the New Zealand Stock Exchange closes one hour earlier than Japan and Australia. These three stock markets can be regarded as overlapping.

Let us suppose that these three stock markets are influenced by the developments of the US stock market. If it is 30th May 2003 all these three markets close before the US stock market opens, therefore these three stock indexes will not respond to the US shock within the same time, instead all these three stock indexes will respond to the US stock with a one-day lag. However, if the US stock market is influenced by the developments of any these three stock indexes, the US stock index would respond to the shocks of these three stock markets on the same day. This is because the trading hours of all these three stock indexes leading on the US stock market. Similarly, since New Zealand Japan and Australia stock exchanges are almost in the same time zone (trading hours are deemed overlapping), if one stock exchange is influenced by another stock exchange, the former should respond to the development of another stock market on the same day. Since the US stock index has one-day lag to other three stock indexes the NYSE (-1) will be used as a US stock index proxy in the daily frequency test and the other three stock indexes can be regarded to influence each other in one single day.

Unit Root Tests: One of the simplest ways to examine the weak form of market efficiency among the four stock markets under study is to use the unit root test to see whether these stock indexes are integrated of order one. If they are integrated with other one, they are regarded to follow at least a weak form efficiency. This 
issue has been addressed by Chan et al. ${ }^{[12]}$, Groenewold and $\mathrm{Kang}^{[13]}$ and Groenewold ${ }^{[1]}$.

The Augmented Dickey-Fuller (ADF) and PhilipPerron (PP) tests are the two most commonly used unit root tests in the economic and financial literature. In this study, we employ both the ADF and PP unit root tests to determine the stationarity of each variable.

Cointegration Test: To test the semi-strong form market efficiency, we employed both the pairwise Engle-Granger and Johansen multivariate cointegration tests $^{[14,15]}$. The Johansen multivariate cointegration

The test enables the simultaneous estimation of the long-run cointegrating relationship between several stock market indices. Johansen developed two likelihood ratio tests for testing the number of cointegration vectors (r): the trace test and the $\operatorname{maximum}^{[16]}$. For the maximum eigenvalue test, both the null and the alternative hypotheses are more specific. When the null of no cointegration $(r=0)$ was rejected, we move up to the next null of $r=1$, but if this null hypothesis is rejected, we then move up to test the null of $r=2$, until the null hypothesis cannot be rejected anymore.

Finally, the number of cointegration relationships (the number of ECM terms) as well as the constant term and deterministic trend should be entered into the model.
The VEC can be written as follows:

$\Delta X_{t}=\sum_{i=1}^{k-1} \Gamma_{1} \Delta X_{t-1}+\alpha\left(\begin{array}{l}\beta \\ \mu_{1} \\ \varphi_{1}\end{array}\right) X_{t-k}+\alpha_{\perp} \mu_{2}+\varphi_{2} D_{t}+\varepsilon_{t}$

Where, $X_{t-k}=\left(X_{t-k}, 1, t\right)$

In this study, the following steps are followed in the Johansen's cointegration testing procedure:

1. The variables are first pre-tested in their order of integration using ADF and PP tests.

2. The model in equation (1) is estimated and rank of $\pi$ is determined. This involves determining which model to choose and the number of ranks employed in the equation is using the likelihood ratio tests results.

3. The normalized cointegration vector(s) and the speed of adjustment coefficients were analyzed and these coefficients tested to investigate whether they are consistent with the existing theory and how much impact these variables have on the dependent variables, by imposing different restriction on $\alpha$ and $\beta$ to see what variable is weak exogenous in the system. This involves hypothesis testing on the restriction of $\alpha$ and $\beta$.

Table 5: ADF and PP Unit Root Test Results on Stock Indexes

\begin{tabular}{|c|c|c|c|c|c|c|c|}
\hline \multicolumn{2}{|c|}{ Stock index return } & \multicolumn{2}{|c|}{ (1) Intercept } & \multicolumn{2}{|c|}{ (2) Trend Intercept } & \multicolumn{2}{|c|}{ (3) None } \\
\hline & & ADF & PP & $\mathrm{ADF}$ & PP & $\mathrm{ADF}$ & PP \\
\hline \multicolumn{8}{|l|}{ NZSEALL } \\
\hline \multirow[t]{2}{*}{ Daily } & Level & -1.437 & -1.514 & -2.286 & -2.38 & 0.031 & 0.0256 \\
\hline & $1^{\text {st }}$ Diff. & -28.375 & -56.408 & -38.371 & -56.401 & -38.381 & -56.416 \\
\hline \multirow[t]{2}{*}{ Weekly } & Level & -1.498 & -1.565 & -2.36 & -2.365 & 0.0792 & 0.0711 \\
\hline & $1^{\text {st }}$ Diff. & -26.091 & -26.119 & -26.075 & -26.103 & -26.109 & -26.136 \\
\hline \multirow[t]{2}{*}{ Monthly } & Level & -1.5789 & -1.5566 & -2.273 & -2.262 & 0.1542 & 0.1556 \\
\hline & $1^{\text {st }}$ Diff. & -13.027 & -13.014 & -12.984 & -12.972 & -13.061 & -13.048 \\
\hline \multicolumn{8}{|l|}{ ASX } \\
\hline \multirow[t]{2}{*}{ Daily } & Level & -1.415 & -1.399 & -2.436 & -2.414 & 1.183 & 1.23 \\
\hline & $1^{\text {st }}$ Diff. & -50.472 & -50.463 & -50.472 & -50.467 & -50.455 & -50.429 \\
\hline \multirow[t]{2}{*}{ Weekly } & Level & -0.8702 & -0.86 & -3.289 & -3.362 & 1.0941 & 1.103 \\
\hline & $1^{\text {st }}$ Diff. & -27.221 & -27.201 & -27.201 & -27.181 & -27.189 & -27.175 \\
\hline \multirow[t]{2}{*}{ Monthly } & Level & -0.8693 & -0.825 & $-3.56 * *$ & $-3.75 * *$ & 1.1763 & 1.273 \\
\hline & $1^{\text {st }}$ Diff. & -13.362 & -13.413 & -13.321 & -13.373 & -13.244 & -13.244 \\
\hline \multicolumn{8}{|l|}{ NIKKEI } \\
\hline \multirow[t]{2}{*}{ Daily } & Level & -1.679 & -1.581 & -2.817 & -2.651 & -1.8 & -1.931 \\
\hline & $1^{\text {st }}$ Diff. & -44.188 & -59.986 & -44.181 & -59.977 & -44.13 & -59.933 \\
\hline \multirow[t]{2}{*}{ Weekly } & Level & -1.582 & -1.591 & -2.631 & -2.678 & -1.927 & -1.937 \\
\hline & $1^{\text {st }}$ Diff. & -26.792 & -26.784 & -26.772 & -26.764 & -26.675 & -26.671 \\
\hline \multirow[t]{2}{*}{ Monthly } & Level & -1.508 & -1.514 & -2.56 & -2.617 & -1.842 & -1.902 \\
\hline & $1^{\text {st }}$ Diff. & -12.405 & -12.408 & -12.365 & -12.367 & -12.185 & -12.186 \\
\hline \multicolumn{8}{|l|}{ NYSE } \\
\hline \multirow[t]{2}{*}{ Daily } & Level & -1.28 & -1.289 & -0.528 & -0.197 & 1.465 & 1.625 \\
\hline & $1^{\text {st }}$ Diff. & -55.425 & -55.412 & -55.44 & -55.453 & -55.393 & -55.344 \\
\hline \multirow[t]{2}{*}{ Weekly } & Level & -1.297 & -1.314 & -0.1261 & 0.0758 & 1.591 & 1.664 \\
\hline & $1^{\text {st }}$ Diff. & -28.623 & -28.819 & -28.67 & -28.94 & -28.538 & -28.647 \\
\hline \multirow[t]{2}{*}{ Monthly } & Level & -1.536 & -1.459 & -0.031 & -0.026 & 1.589 & 1.95 \\
\hline & $1^{\text {st }}$ Diff. & -14.782 & -14.938 & -14.946 & -15.433 & -14.5 & -14.495 \\
\hline
\end{tabular}

Notes: Level $=$ the log of market stock price indices, $1^{\text {st }}$ Diff. $=$ the change of log stock market price level. 
Granger-causality Test: We run the Granger-causality test as an alternative method to cointegration test the semi-strong form market efficiency. The Grangercausality tests can be used to measure how the percentage of the first variable explains the movement of the second variable ${ }^{[17]}$. It also can be carried out in the reverse order.

\section{RESULTS AND DISCUSSION}

Weak Form Efficiency: ADF and PP Unit Root Tests: The ADF and PP unit root test results are presented in Table 5. The results showed that all stock indexes in level (except ASX in monthly frequency with the trend and intercept terms is rejected at the 5\% significance level) are non-stationary and all stock indexes in the first difference are stationary indicating that they are all integrated of order one. Adding or omitting the intercept and trend terms do not seem to change the results of the ADF and PP tests.

Our daily results are similar to Groenewold ${ }^{[1]}$ findings that both the New Zealand and Australian stock indices is integrated of order 1. This finding is consistent with the weak form market efficiency. Our results remain robust when weekly and monthly data are used except for ASX when monthly data is used. The stationarity of NIKKEI and NYSE stock indices in first difference also suggest that similar to the NZSE and ASX stock indices, their market can be characterized by at least weak form market efficiency.

\section{Semi-Strong Form Efficiency: Cointegration and Granger Causality Tests:}

Engle-Granger Cointegration Test: Table 6 reports the results of the Engle-Granger pairwise cointegration tests. The results indicate that the cointegration relationship between two stock indexes is rejected in the following markets: the NZSEALL cannot be used to explain the ASX movement and no individual stock index can be used to explain the movement of the Nikkei 225 when considered in pairs. Neither the Japanese nor the US stock indexes can be used to explain the movement of each other. This implies that the US and Japan stock markets are quite independent, which has been identified by other researchers such as Chan et al. ${ }^{[11]}$ and Eun and Shim ${ }^{[12]}$. Furthermore, the results show that the NZSEALL stock index does not follow a semi-strong form efficient as it can be predicted using other stock market indexes. On the other hand the Japanese stock index behaved more efficiently than the rest of the stock markets since no single stock market index under study can be used to predict the movement of the Japanese stock index.

Johansen's Multivariate Cointegration Test: Using daily data, the appropriate lag length of Johansen's cointegration test to estimate the relationships among the comovement of different stock indexes is determined to be 24 . The estimated relationship among these variables can be expressed as:

NZSEALL $=1.4096($ ASX $)+0.1991$

(NIKKEI) -0.6104 (NYSE (+1))

This implies that NZSEALL is positively related with ASX and NIKKEI but negatively related to NYSE (-1) using daily data.

As a robustness check, we also run the Johansen's cointegration test using weekly data. Employing weekly data, the lag length was determined to be 5 . The longrun relationship can be expressed as follows:

NZSEALL=3. $102($ ASX)

+0.466 (NIKKEI) -1.371 (NYSE)

The coefficient signs of the weekly data in equation (3) are consistent with the daily data in equation (2) but each estimated parameter is 2.2 to 2.5 times bigger than in equation (2). This implies that all these stock indexes behaved stronger relationship with the NZSEALL using weekly data.

\section{Granger causality Test:}

NZSE and ASX: Table 7 reports the Granger-causality test results using daily data.

Test results in Table 7 imply that using daily data the ASX index return was found to Granger-cause the NZSE index return but the NZSE index return does not Granger-cause the ASX index return. This result is consistent with the findings using the Engle-Granger's cointegration test shown in Table 2 but is inconsistent with Groenewold ${ }^{[1]}$, $s$ findings that returns in New Zealand and Australia help explain the current return of each other, although the proportion of variation explained is small if using daily data. The differences in the results could be attributed to the different data frequency as indicated by Groenwold ${ }^{[1]}$.

Table 6: Engle-Granger Cointegration Test of Stock Returns

\begin{tabular}{|c|c|c|c|c|}
\hline $\begin{array}{l}\text { Dependent } \\
\text { Market }\end{array}$ & $\begin{array}{l}\text { New Zealand } \\
(\mathrm{NZ})\end{array}$ & $\begin{array}{l}\text { Australia } \\
(\mathrm{AU})\end{array}$ & $\begin{array}{l}\text { Japan } \\
(\mathrm{JP})\end{array}$ & $\begin{array}{l}\text { US } \\
\text { (US) }\end{array}$ \\
\hline NZ (Daily) & & -2.437 & -2.098 & -2.289 \\
\hline (Weekly) & & -2.129 & -2.004 & -2.242 \\
\hline (Monthly) & & -2.077 & -2.025 & -2.211 \\
\hline AU (Daily) & $-1.117 * * *$ & & -2.010 & -2.064 \\
\hline (Weekly) & $-1.796^{*}$ & & -2.159 & -2.223 \\
\hline (Monthly) & $-1.356^{* * *}$ & & -2.249 & -2.522 \\
\hline JP (Daily) & $-2.649 * * *$ & $-1.346^{* * * *}$ & & $-1.858 * *$ \\
\hline (Weekly) & $-2.43 * * *$ & $-2.573 * * *$ & & $-1.805 * *$ \\
\hline (Monthly) & $-2.42 * * *$ & $-2.626 * * *$ & & $-1.806 * *$ \\
\hline US (Daily) & -2.118 & -2.016 & $-1.413 * * *$ & \\
\hline (Weekly) & -2.117 & -2.328 & $-1.397 * * *$ & \\
\hline (Monthly) & -2.021 & -2.650 & $-1.477 * * *$ & \\
\hline
\end{tabular}

Note: $5 \%$ critical value is -1.94 , $*$ Significant at $1 \%$ level, **Significant at $5 \%$ significant level, $* * *$ Significant at $10 \%$ level 
Table 7: Granger-Causality Test Among Four Stock Indexes

\begin{tabular}{lllll}
\hline Variables & NZSEALL & ASX & NYSE (+1) & NIKKEI \\
\hline Daily & & & & \\
NZSEALL & & - & - & - \\
ASX & $1 \%$ & & - & - \\
NYSE (+) & $1 \%$ & $1 \%$ & & $1 \%$ \\
NIKKEI & - & - & - & \\
& & & & \\
Variables & NZSEALL & ASX & NYSE & NIKKEI \\
Weekly & & & & \\
NZSEALL & & - & - & $5 \%$ \\
ASX & - & & $5 \%$ & $10 \%$ \\
NYSE & - & $1 \%$ & & - \\
NIKKEI & - & - & - &
\end{tabular}

Note: Symbol "-" means variable in a row does not granger cause variation in column. The number indicates how much percentage the variables in column granger cause variables in a row.

The cointegrating relationship between Australia and New Zealand could be attributed to their strong economic ties and close geographic proximity ${ }^{[2,18]}$.

Using weekly data, the results are similar to the daily data results: the ASX index return Granger-caused the NZSE index return but the opposite is not true. In other words, the NZSE index return does not help explain the Australian Stock index return. The weekly test result in this study is consistent with Groenewold ${ }^{[1]}$,s findings that using weekly data, only past Australian returns help explain New Zealand returns. Hence, by employing Granger-causality tests this study failed to find the semi-strong market efficiency in the New Zealand Stock market using daily and weekly data.

NZSE, ASX, NYSE and NIKKEI Indexes: Finally, the Granger-causality of stock indexes with New Zealand's three major trade partners, namely, Australia, Japan and the US are examined. The results of the Granger-causality test results among these stock indexes are summarized in Table 7. Using daily data, the test results imply that NYSE $(+1)$ and ASX Grangecause the NZSEALL at the $1 \%$ significance level, NYSE (+1) Granger-cause ASX and NIKKEI at 1\% significance level. However, the NIKKIE was not found to Granger-cause any other stock indexes as indicated by Ghosh et al. ${ }^{[4]}$ and Eun and Shim ${ }^{[11]}$.

This test result is quite reasonable. Since the US stock index has a one-day lag before it opens the NYSE stock index is influenced by the NIKKEI and ASX because these two markets have already traded for 5-6 hour in this single day, while the NZSEALL only has another half hour of trading before the NYSE opens, therefore, the impact of the NZSEALL index on the NYSE (+1) stock index is quite minor compared with the ASX or NIKKEI.
As a robustness check, we also run the grangercausality tests using weekly data. The results are reported in Table 7. Using weekly data, the ASX was found Granger-causing the NYSE at the 5\% significance level while the NYSE Granger-caused the ASX at the $1 \%$ significance level. In addition, both ASX and NZSE Granger-caused the NIKKEI stock index, which has not been found in the results employing daily data. Consistent with the daily results, the weekly results also revealed that the NIKKEI and NYSE stock indexes are independent and do not Granger-cause each other.

\section{CONCLUSION}

The objective of this study is to re-examine the market efficiencies in New Zealand and Australia by testing whether Groenewold's ${ }^{[1]}$ findings still hold in the period after the financial liberalization (January 1990 to January 2003). In addition, we also examine whether the larger US NYSE index and a Japanese NIKKEI index have any influence on the NZSE and ASX indices.

In general, we can conclude that the NZSE40 is determined by the interest rate movement, money supply and real GDP over this research period. With regard to New Zealand Stock Market's efficiency, although ADF and PP unit root test results on the NZSE stock index indicates that it follows the weaker form efficiency, however, the estimated parameter for in the VEC model is -0.339 , which implies that approximately $34 \%$ of the previous period's disequilibrium error is corrected each month. This indicates that the semi-strong efficiency of New Zealand Stock Market is mildly violated. When testing the New Zealand Stock market efficiency using Groenewold' ${ }^{[1]}$ method we found the result is consistent with the previous findings. Using daily and weekly data the Australian stock index was found to Granger-cause the New Zealand stock index, which also implies that New Zealand Stock market does not follow a semi-strong form of efficiency.

When considering the comovement of stock indexes among New Zealand Australia, Japan and the US, the New Zealand stock index was found to be largely Granger-caused by the Australian stock index using daily and weekly data. Further, using Johansen's cointegration equation at different frequencies the New Zealand stock index was found to be positively related to the Australian and Japanese stock indexes but negatively related to the US stock index. In general, the New Zealand stock index was found to be largely cointegrated with the Australian Stock index while the stock index of Japan and the US is slightly independent of each other.

Although the NZSE is a relatively small stock market, the stock index is relatively independent; it is neither Granger-caused by the US nor by Japan. Our 
granger-causality results further show that the NZSE stock index are Granger-caused by the ASX stock index and that the NYSE and NIKKEI stock indexes seem to be independent and have no influence on each other.

Our findings of violation in the semi-strong form of market efficiency of the NZSE stock index suggests that there are opportunities for investors to obtain abnormal returns by observing publicly available information. For policy makers, the findings that the movement of a particular NZSE stock index is dependent on the ASX stock index would suggest that they need to be aware of information affecting the ASX as it would affect the NZ equity market as well.

For investors who want to invest in more than one stock market, the US stock market should be considered because the stock indexes in New Zealand and the US do not move in the same direction. Therefore, investors would benefit from risk diversification of investments.

For policy makers, they should know that the movement of the New Zealand stock index is largely dependent on the Australian Stock index. This implies that the NZSEALL did not follow the semi-strong form efficiency. The policy makers can consider enlarging New Zealand's share market capacity by issuing more shares and encouraging more foreign companies to list on the New Zealand stock exchange. This will benefit the New Zealand economy and attract more foreign investors to invest in New Zealand.

In addition to using stock indices of other countries as 'other publicly available information', future study could also include other macroeconomic variables as explanatory variables when testing market efficiency. Future studies could also investigate the changes in equity market efficiency surrounding a specific event (macro 'event-study') such as the 1997 Asian crisis period, or the burst of the IT industry bubble in the year 2000-2001.

\section{REFERENCES}

1. Groenewold, N., 1997. Share market efficiency: Tests using daily data for Australia and New Zealand. Applied Financial Economics, 7: 645-657

2. Hassan, M.K. and A. Naka, 1996. Short-run and long-run dynamic linkages among international stock markets. Intl. Rev. Economy. Finance, 5: 387-405.

3. Ghosh, Saida and Johansen, 1999. Who moves the Asia-Pacific stock markets US or Japan? Empirical evidence based on the theory of cointegration. The Financial Rev., 34: 159-169.
4. Durand, R.B., K.S. Kee and I. Watson, 2001. Who moved Asian-Pacific stock markets? A further consideration of the impact of the US and Japan. Australian J. Managua., 26: 125-145.

5. Kwon, C.S. and T.S. Shin, 1999. Cointegration and causality between macroeconomic variables and stock market returns. Global Finance J., 10: 71-81.

6. Phillips, P.C. and P. Perron, 1988. Testing for a unit root in time series regressions. Biometrics, 75: 335-346.

7. $\mathrm{Yu}, 2003$. Forecasting volatility in the New Zealand stock market. Department of Economics, University of Auckland Working Paper Series.

8. Brailsford, T., 1995. Time varying volatility and the impact of economic reform on the New Zealand stock market. Working Paper Series in Finance, The Australian National University, Canberra.

9. Cheung, Y.W. and $\mathrm{Ng}, 1998$. International evidence on the stock market and aggregate economic activity. J. Empirical Finance, 5: 281-296.

10. Eun and Shim, 1989. International transmission of stock market movement. J. Financial and Quantitative Analysis, 24: 241-256.

11. Chan, Gup and Pan, 1992. An empirical analysis of stock prices in major Asian markets and the United States. The Financial Rev., 27: 289-307.

12. Groenewold, N. and K.C. Kang, 1993. The semistrong efficiency of the Australian share market. The Econom. Rec., 69: 405-410.

13. Enders, W., 1995. Applied Econometric Time Series. John Wiley and Sons Inc., United States.

14. Engle, R.F. and C.W.J. Granger, 1987. Cointegration and error correction: Representation, estimation and testing. Econometrica, 55: 251-276.

15. Johansen, S., 1988. Statistical analysis of cointegration vectors. J. Economic Dynamics and Control, 12: 231-254.

16. Granger, C.W.J., 1988. Some recent developments in a concept of causality. J. Econometrics, 39: 199-211.

17. Dekker, K. Sen and M.R. Young, 2001. Equity market linkages in the Asia-Pacific region: A comparison of the Orthogonalised and generalized VAR approaches. Global Finance J., 12: 1-33. 